\title{
Temel Tasarım Dersine İlişkin Öğrenci Görüşleri
}

\author{
Emrah UYSAL *
}

Özet

Bumakale, lisans düzeyindeki Temel Tasarım dersinin etkililiğine dairöğrencigörüşlerinin belirlenmesiniamaçlamaktadır. Araştırma, Aksaray Üniversitesi, Eğitim Fakültesi, Güzel Sanatlar Eğitimi Bölümü, Resim-iş Eğitimi Anabilim Dalı’nda eğitim gören 17 öğrenci üzerinden yürütülmüştür. Veri toplamada 8 soruluk yarı yapılandıııııı̧ görüşme formu kullanılmış, verilerin analizinde NVivo 8 programı tercih edilmiş̧ir. Öğrenci görüşlerinin değerlendirilmesinde ise içerik analizi yapılmış ve elde edilen bulguların frekansları tespit edilmiştir. Araştırma sonucunda lisans düzeyindeki Temel Tasarım dersinin genel olarak etkili olduğu belirlenmiş̧tir.

Anahtar Sözcükler: Sanat Eğitimi, Temel Tasarım Eğitimi, Temel Sanat Eğitimi, Yaratıııık, Bauhaus.

\section{Students' Views on the Course of Basic Design}

\section{Abstract}

This paper aims to determine students' views on the effectiveness of the Basic Design Course at undergraduate level. The research is carried out with 17 students who enrolled Aksaray University, Faculty of Education, Department of Arts and Crafts. Data were collected by semi-structured interviews comprised of 8 questions and NVivo 8 software program were utilized. In evaluating students' views, content analysis is applied and frequencies of data are provided. It is found that the basic design course at the undergraduate level is generally effective.

Keywords: Art Education, Basic Design Education, Basic Art Education, Creativity, Bauhaus. 


\section{Giriş}

Sanat eğitiminin amacı, bireyi, sosyal konular içinde yaşadığı toplum hakkında bilinçlendirmek ve bireye sorumluluk yüklemektir. Aynı zamanda, bireyin toplum içerisindeki farkındalığını artırmak, yaşamını en iyi biçimde sürdürüp bireye kendini geliştirme olanakları sunmak, bireyin doğanın sunduğu tüm olanaklardan yararlanmasını, kendi gizil gücünü harekete geçirmesini, kendini iyi biçimde ifade etmesini sağlamaktır. Sanat eğitiminin, insan hayatında önemli bir yeri olduğunu düşünen Tepecik'e göre (2012: 12) sanatın tanımı şu şekildedir: "Insanın ihtiyaçları sıralamasında, birinci amaç karnımızı doyurmak, barınmak ve üremektir, yani hayatta kalmaktır. İkinci kademede, çeşitli eğitim faaliyetleri ve sanat yer alır, bu bilgiler içersinde sanat önemli bir yer tutar, çünkü çocuğun ileriye dönük ilgi alanı sanat eğitiminde ortaya çıkabilir”. 20. yüzyılın başlarından itibaren sanat eğitimi genel anlamda güzel sanatların bütün alanlarını kapsayan okul içi ve dışı yaratıcı sanatsal eğitim olarak tanımlanabilir.

Bu eğitim sürecinin ana ilgilerinden olan 'Temel Sanat Eğitimi/Temel Tasarım Eğitimi' dersi de sanat eğitiminin yapılanmasında ilk adımdır. Temel Tasarım dersi, eğitim fakültelerinin güzel sanatlar eğitimi bölümleri ve güzel sanatlar fakültelerinin lisans düzeyinde birinci sınıf öğrencilerinin güz-bahar dönemlerinde aldıkları zorunlu derstir. Temel Tasarım I dersinin içeriği, sanat eserini oluşturan elemanlar (çizgi, doku, form, şekil, mekan) ve ilkeler (ritim, hareket, denge, vurgu, kontrast, birlik, bütünlük, çeşitlilik), iki boyutlu yüzey üzerine iki boyutlu ve üç boyutlu uygulama çalışmalarını kapsamaktadır (YÖK, 2010). Temel Tasarım II dersinin içeriğinin ise, tasarım eleman ve ilkeleri kullanılarak renkli ve üç boyutlu çalışmalara daha da ağırlık verilmesi, ortaya çıkan ürünlerin görselleştirilmesi olduğu belirtilmektedir (YÖK, 2010).

Temel tasarım eğitimi dersinde, öğrencinin görsel anlamda kişilik gelişimini sağlaması, plastik değerleri kavraması, duyu algılarını geliştirmesi, yeni formlar oluşturması, nesneler arası ilişkiler kurması ve bu ilişkileri belli tasarım ilkeleri doğrultusunda düzenlemesi amaçlanmaktadır. Ayrıca bu ders, öğrencinin yaratıcılığını geliştirmesinin yanı sıra, üretilen imgelere estetik açıdan değer kazandırarak, öğrencinin estetik üretim duyarııığını çalışmalarına yansıtabilmesini amaçlar. Temel Tasarım kavramı 20. yüzyılın başlarında Almanya'da Tasarım Okulu olarak Bauhaus'ta kullanılmış, öğrencilerin kişisel olarak kendilerini tanımalarına yardımcı olmak adına, önceden edinilmiş ön yargılardan kurtulmalarını amaçlayan bir disiplin olarak öğretim programlarında yer almıştır. Görsel eğitimi modern bir yaklaşımla şekillendirmeye çalışan Bauhaus Okulu, sınıflara hazırlık sistemi ve özgün öğretim yöntemleriyle görsel eğitime büyük katkıda bulunmuştur. Bauhaus, güzel sanatlar alanını diğer uygulamalı sanatlarla bir araya getirerek sınırları ortadan kaldırmış, sanatı tasarım yoluyla gündelik yaşamın içerisine sokmayı amaçlamıştır. Öğrenci çalışmalarına bakıldığında gözleme dayalı etütler, hafızadan etütler, doku çalışmaları, natürmortlar ve malzeme ile yapılan çalışmalar bu okulda uygulanan doğal obje kaynaklı çalışmalar olarak görülmektedir. Bauhaus okulununönemli hocalarından biri olan Itten, “... öğrencilerine doğadan yapılan çalışmaların yanında eski ustaların yapıtlarını, kompozisyon, doku ve strüktüel açıdan inceleterek, yardımcısı Gretrude Grurov ile sezgilere dayalı bir öğretim yaptırmıştır" (Feierabend ve Fiedler, 2000: 242'den). Burada amaç, eseri algılama, anlama, çizgisel ve kompozisyon olarak değerlendirebilme deneyimini kazandırmaktır. Ayrıca, Bingöl'ün de (1993:10) belirttiği gibi, Itten'in verdiği kursların önemli bir kısmını oluşturan diğer bir konu da renkler ve renk bilgisi üzerine yaptığı seminerlerdir. Ana renkler, tamamlayıcı renkler ve zıt renklerle bunların siyah ve beyaz renk düzlemleri üzerindeki etkileri araştırılmıştır. Renklerin psikolojik etkisi ve ne anlam ifade ettiği araştırılarak, uygulamalı çalışmalarla deneyimlenmiştir. Bu uygulama çalışmaları, görsel algılamanın bir sonraki aşamasını oluşturan kuramla desteklenerek tamamlanmaya çalışılmıştır. Itten, bu çalışmalardan elde ettiği örnekleri sonradan bir araya getirerek 1961 yılında 'Kunst und Farbe' (Sanat ve Renk) 
adıyla kitap haline getirip yayınlatmıştır (Bingöl, 1993: 10).

Öğrencilerin renklerle biçimler arasındaki ilişkiler üzerinden araştırma ve denemeler yapmalarını isteyen Kandinsky de, özellikle soyut sanat ve doğa arasındaki ilişkinin varlığından söz ederken, bu durumu çeşitli örneklerle açıklamıştır. Nokta ve çizginin varlığını tohum ve filizlenme olarak açıklar (Lynton, 1991: 280). Örneğin, gelincik üzerinde yapılan bir incelemede nokta ve çizgi arasındaki kompozisyon kurgusu fizik yasalarına dayandırılarak açıklanırken içlerindeki rengin düzeni bu örneği daha güçlü hale getirir. Bu araştırma ve incelemelerden hareketle toplanılan örnekler Kandinsky'nin Bauhaus okulu için hazırlamış olduğu ‘Nokta ve Çizgiden Düzleme-1926’ adlı kitabında bir araya getirilerek bu dersin temelini oluşturmuştur (Lynton, 1991: 280-283).

Temel tasarım, birçok ülkede görsel sanatlar ile ilgili çeşitli programlarda 'Basic Design' adıyla yer almaktadır. Bu sözcük ilk kez Bauhaus öğretmenlerinin araştırmalarından doğmuştur. Turani'ye göre (1998: 21), 'Basic Design', çizgi, nokta, hacim, yüzey ve renk gibi sanatsal ilke ve elemanlardan yararlanarak uygun kompozisyon oluşturmak, yaratıcılığın ön plana çıkarıldığı biçimleyici çalışma ve malzemenin imkânları araştırılarak yapılacak, biçimlendirme ve düzen çalışmaları olarak tanımlanmaktadır. Temel Tasarım dersi, Türkiye'de ilk kez 1957 yılında İstanbul Tatbiki Güzel Sanatlar Yüksek Okulu'nun programına alınmıştır. Atar'a göre (2004: 47), ortak bir dilin öğretisiyle yeniden yapılandırılan bu ders, sonraları, grafik, seramik, iç mimarlık v.b. diğer bölümlerin öğretim programlarında da yerini almıştır. Sanat eğitimi veren kurumların birinci sınıfında zorunlu olarak, bir yıl süreyle hazırlayıcı eğitim olarak uygulamaya konulmuştur.

\section{Araştırmanın Amacı}

Bu çalışmanın amacı, lisans düzeyindeki Temel Tasarım dersinin uygulamadaki etkililiğine ilişkin öğrenci görüşlerinin belirlenmesidir.

\section{Yöntem}

\subsection{Araştırmanın Modeli}

$\mathrm{Bu}$ çalışma nitel desende gerçekleştirilmiştir. Nitel araştırmalarda veri toplama aracı olarak geliştirilen araçlardaki görüşler içerik analizi yöntemiyle değerlendirilmesi söz konusudur. Ayrıca gözlem, görüşme ve doküman analizi vb. veri toplama yöntemleri nitel araştırmalarda kullanılırken, algılarla olaylar doğal ortamda gerçekçi ve bütüncül bir biçimde belirlenmeye çalışılır (Yıldırım ve Şimşek, 2005: 39).

\section{2. Çalışma Grubu}

Bu çalışma, 2014-2015 eğitim-öğretim yılında, Aksaray Üniversitesi Eğitim Fakültesi Güzel Sanatlar Eğitimi Bölümü Resim-iş̧ Eğitimi Anabilim Dalı'nda lisans düzeyinde eğitim gören 17 üniversite öğrencisi üzerinden gerçekleştirilmiştir. Öğrencilerin 14'ü kadın, 3’ü de erkektir. Öğrencilerin hepsi lisans düzeyindeki birinci sınıf öğrencileridir.

\subsection{Veri Toplama Aracının Geliştirilmesi}

Çalışma kapsamında 8 soruluk bir görüşme formu veri toplama aracı olarak uygulanmıştır. Bağımsız düşünebilme için açık uçlu sorular tercih edilmiştir. Gerektiğinde ek sorular yöneltilerek yarı yapılandırılmış görüşme gerçekleştirilmiş̧ir. Her soru farklı veriler için hazırlanmıştır. Görüşme formu geliştirilirken önce ilgili alan-yazın taranıp taslak form hazırlanmıştır. Bu form, 5 Resim-Iş öğretmeninin görüşlerine sunulmuş; daha sonra ilgili ölçek içerik geçerliliği bakımından, Aksaray Üniversitesi öğretim üyelerinin değerlendirmelerine sunulmuştur. Uzman görüşleri ışığında ilgili form üzerinde gerekli düzeltmeler yapılmış ve son şekli verilmiştir.

\subsection{Verilerin Analizi}

Tüm veriler bilgisayara aktarılmış, içerik ve betimsel analiz yöntemleri kullanılmıştır. Katılımcıların özelliklerini tanımlamayı hedefleyen betimsel istatistik, bir örneklemden hareketle gözlem yaparak elde edilen verileri kullanmaktadır. Araştırmada öğrencilere 
yöneltilen sorulara verilen cevaplar, eleman ve ilkeler, özgün tasarımlar, malzeme kullanımı, sanat tarihi ile ilişkisi, yaratıcılık, sanat eserleri ile ilişki, teknoloji kullanımı, görüş ve öneriler boyutlandırılmıştır. Benzer cevapların yer aldığı kategorilerin toplam içerisindeki frekansları tablolar şeklinde gösterilmiş ve tablolardaki veriler yorumlanmıştır.

\begin{tabular}{|c|c|}
\hline Eleman ve filkeler fie Iiliskisi & $\mathbf{f}$ \\
\hline Kuram ve Uygulama & 12 \\
\hline Disipline Olma & 3 \\
\hline Görmeyi Ofgrenme & 3 \\
\hline Yol Gớsterici & 3 \\
\hline Hayal Gūeû & 1 \\
\hline
\end{tabular}

Tablo 1: Öğrencilerin “Eleman ve Ilkeler” ile ilgili Görüşleri

\section{Bulgular ve Yorum}

Bu bölümde araştırma ile ilgili elde edilen bulgular belirlenen alt amaçlar doğrultusunda alt başlıklar halinde sunulmaktadır. Araştırmanın amacına yönelik olarak Resim-Iş̧ Eğitimi öğrencilerine yöneltilen ilk soru 'Temel tasarım dersinin temel sanat eleman ve ilkelerini size tanıtabilmesi hakkındaki düşünceleriniz nelerdir?' şeklinde olmuştur. Öğrencilerin verdikleri cevaplardan elde edilen görüşler şu şekildedir:

Araştırma kapsamında öğrenciler olumlu $(n=22)$ görüşler ortaya koymuşlardır. Öğrencilerin bazılarının görüşleri şu şekildedir:

Ö-13: Vurgu, kompozisyon, yakınlık gibi temel öğelerin öğretimi ve daha sonra uygulanması noktasında deneyimim oldu.

0̈-14: Temel tasarım dersi renkleri, çizgileri ve lekeleri doğru zamanda doğru yerde kullanmam için bana çok şey kazandırdı.

Temel sanat eleman ve ilkelerinin tanıtımında öğrencilerin kuramsal ve özellikle uygulamalı olarak beslendiklerine dikkat çekilmiştir.

Ö-12: Bir objeyi çizerken onu daha gerçekçi çizebilmek için leke, çizgi, nokta, değer gibi elemanları nasıl ve nerede kullanmam gerektiğini öğrendim. Daha kontrollü ve temiz çalışmamı sağladı.

Temel tasarım dersinin öğrenciyi disipline eden bir ders olduğu belirtilmiştir.

0̈-2: Çizim yaparken bakıp çizmeyi değil, görüp çizmeyi sağladı. Daha dikkatli ve titiz çalışıyorum.

Bakmak ve görmek arasındaki farkın öğrenildiğine, öğrencilerin özellikle kuram ve uygulamada eleman ve ilkelerle ilgili beslendiklerine dikkat çekilmiştir. Bu durumda eleman ve ilkelerin tanıtımına yönelik öğrencilerin gerekli donanımı kazandıkları düşünülebilir. Özellikle de uygulama anlamında gerekli kazanımları elde ettikleri sonucuna gidilebilir. S.Buyurgan ve U.Buyurgan'a göre (2001: 53), üniversitelerde verilen Temel Sanat Eğitimi/Temel Tasarım dersinde öğrenciye yüzeyler üzerine iki ve üç boyutlu çalışmalarla sanatın ilke ve elemanlarının kavratılması amaçlanır. Böylelikle öğrenciler nokta, çizgi, biçim (form), doku, renk, ton gibi unsurları öğrenerek farklı malzemeler kullanma ve yeni formlar oluşturma konusunda beceri sahibi olurlar. Ayrıca öğrenciler ileriki yıllarda görecekleri dersler için de alt yapılarını zenginleştirirler ve görsel ifade güçlerini kullanarak görsel bilginin organizasyonunu geliştirirler. Yine öğrenci görüşlerine bakıldığında, dikkatli ve titiz çalışma konusunda disipline olmalarını sağlayan bir ders olduğu konusuna vurgu yaptıkları gözlenmektedir. Zaten temel tasarım dersinin disipline etme konusunda önemli bir ders olduğu bilinmektedir. Öte yandan bakma ile görme arasındaki farkı algılamalarını sağlayan bir eğitim modeli ile karşılaştıklarını belirtmişlerdir. Bakma ve görme arasındaki farkı öğrenme yalnızca temel tasarım dersi hedeflerinden olmayıp dört yıllık eğitim sürecinin de ana hedeflerinden biridir. Aslında bitmeyen bir sürecin parçasıdır. Bunların yanı sıra öğrencilerin görüşlerine tekrar bakıldığında, eleman ve ilkelerin yol gösterici olduğuna, hayal gücünü geliştirdiğine dikkat çekilmiştir.

Araştırmaya katılan Resim-İ̧̧ Eğitimi öğrencilerine yöneltilen ikinci soru 'Temel tasarım dersinin temel sanat eleman ve ilkelerini özgün tasarımlar şeklinde uygulamanızı sağlaması hakkındaki düşünceleriniz nelerdir?' şeklinde düzenlenmiştir. 


\begin{tabular}{|c|c|}
\hline Ongün Tasanmiar & f \\
\hline Yaraticılik & 8 \\
\hline Yol Gōsterici & 5 \\
\hline Organtak & 4 \\
\hline Bireysel Farklilik & 4 \\
\hline Ozgũvea & 3 \\
\hline Hayal Gūcō & 2 \\
\hline Duygu & 1 \\
\hline
\end{tabular}

Tablo 2: Öğrencilerin “Özgün Tasarımlar” ile Illgili Görüşleri

Araştırmaya katılan öğrenciler olumlu $(n=27)$ görüşler ortaya koymuşlardır. Öğrencilerin bazılarının görüşleri şu şekildedir:

0̈-7: Çizimlerde vereceğimiz etkinin bireysel farklıı̆̆ını sağlar. Daha yaratıcı olmamızı, özgün çizimler yapmamızı sağlar.

Ö-11: Özgün tasarımlar gerçekleştirerek diğer alanlarla ilişkiler kurmamızı ve yaratıcılığı geliştirmemizi sağlar.

Temel tasarım ilke ve elemanlarının özgün tasarımlar üretmede yaratıcıllğa önemli katkısı olduğuna dikkat çekilmiştir.

0̈-6: Daha soyut ve somut çizimimi, hayal gücümü geliştirdiğini gördüm. Kendimize ait tasarımlar yaratmayı öğrendim. Sadece bakmakla resim yapılmaması gerektiğini düşünüyorum.

0̈-11: Özgün tasarımlar gerçekleştirerek diğer alanlarla ilişkiler kurmamızı ve yaratıcılığı geliş̧irmemizi sağlar.

Temel tasarım dersinin özellikle soyut ve somut düşünme aşamasında yol gösterici olduğu vurgulanmış, ayrıca duygu ve düşünceleri aktarmada ve diğer alanlarla ilişki kurmada da etkili olduğuna dikkat çekilmiştir.

0̈-2: Bireysel farklııklar sağlar. Kısıtlayarak değil özgürce çalışma imkânı sağlar.

Temel tasarım dersinin sınırları ortadan kaldıran, özgür kılan bir yapısı olduğu vurgulanmıştır.

Ö-2: Bireysel farklılıklar sağlar. Kısıtlayarak değil özgürce çalışma imkanı sağlar.
Öte yandan bu dersin bireysel farklılıkları ortaya çıkardığı konusuna dikkat çekilmiştir.

0̈-3: Özgün sanat uygulamalarında kendimize karşı öz güvenimizi arttırır.

Yine bu dersin öz güveni geliştirdiği yönünde görüşlere dikkat çekilmiştir.

0̈-6: Daha soyut ve somut çizimimi, hayal gücümü geliştirdiğini gördüm. Kendimize ait tasarımlar yaratmayı öğrendim. Sadece bakmakla resim yapılmaması gerektiğini düşünüyorum.

Özgün tasarımlar üretmede temel tasarım dersinin hayal gücünü geliştirdiği yönünde görüş alınmıştır.

Yaratıcı düşünmeyi geliştirdiği ve ön plâna çıkardığı, daha yaratıcı işler üretmeyi sağladığı yönünde görüşler öne çıkmıştır. Gümrah'a göre (2002: 228), Temel sanat eğitimi, amaç, kapsam ve program olarak, yaratıcı bireyin eğitim ve öğretimini amaçlar. Teknik bilgilerin verildiği eğitim-öğretim değil, yapısı gereği görsel algı, düşünce, estetik canlandırma, simülasyonun (benzetim) yönteminin zihinsel yapılaşması, buluş-esin kaynağı ve yaratıcılık süreci, el-göz-beyin yeteneklerinin geliştirilip arttırılması, düş gücü, hayal dünyası ve sezgisel güçlerinin etkinleştirilmesi eğitimi ve öğretimidir. Temel tasarım dersi Gümrah'ın (2002: 228) da belirttiği gibi, teknik bir eğitim-öğretimin ötesindedir ve yukarıda belirtildiği gibi yaratıcılık sürecini de etkinleştiren bir derstir. Bulgulara bakıldığında da öğrencilerin yaratıcılıklarını geliştirdiği yönünde görüşler elde edilmesi olumlu bir sonuç olarak düşünülmektedir. Aynı zamanda bireysel farklılıkların ortaya çıkarıldığı, buna ilişkin farkındalıklarının geliştiği ve öz güven sağladığı, hayal gücünü geliştiği yönündeki görüşlerin de önemli olduğu düşünülmektedir.

Araştırmaya katılan Resim-İ̧̧ Eğitimi öğrencilerine yöneltilen üçüncü soru 'Temel tasarım dersinin temel tasarımda kullanılan çeşitli malzemeleri etkin bir şekilde kullandırabilmesi hakkındaki düşünceleriniz nelerdir?' şeklinde düzenlenmiştir. 


\begin{tabular}{ll}
\hline Malzeme Kallanımı & f \\
\hline Malzeme Kullanima & 6 \\
\hline Ozgüven & 3 \\
\hline Teknik & 3 \\
\hline Hayal Gũeũ & 2 \\
\hline Orgünlük & 2 \\
\hline Disipline Olma & 1 \\
\hline Renk Hliskisi & 1 \\
\hline
\end{tabular}

Tablo 3: Öğrencilerin “Malzeme Kullanımı” ile Ilgili Görüşleri

Temel Tasarım dersinin etkililiğine ilişkin yapılan araştırmada, temel tasarım dersinin temel tasarımda kullanılan çeşitli malzemeleri etkin bir şekilde kullandırabilmesi ile ilgili olarak bir soru yöneltilmiştir. Araştırmaya katılan öğrencilerin olumlu $(n=15)$ görüşler yanı sıra olumsuz $(n=3)$ görüşler de ortaya koymuşlardır. Öğrencilerin bazılarının görüşleri şu şekildedir:

\section{0̈-5: Malzemelerin doğru biçimde kullanımı} çalışmalarımızı istediğimiz biçimde gerçekleştirmemizi sağlar. Disiplinli boyama yapmayı öğrenerek bilinçli boyama ve bilinçsiz boyama yapmayı öğretmektedir.

0̈-7: Temel tasarım dersinde kullandığımız her malzeme ayrı bir fikir, ayrı bir ilham veriyor. 0 yüzden bu dersin ileriye dönük büyük bir yatırım olduğunu düşünüyorum.

Temel tasarım dersinin çeşitli malzemeleri etkili bir şekilde kullandırabilmesine ilişkin alınan olumlu görüşlere bakıldığında; malzemeyi doğru biçimde kullanmayı öğrenmede, eğlenceli ve yaratıcı işler üretmede yardımcı olduğunu vurgulayan ve ayrı bir düşünme, esin kaynağı olması ile ilgili görüşlerin dikkat çektiği görülmektedir. Aynı zamanda malzeme kullanımına ilişkin olumsuz görüşlere de rastlanmıştır. Bazıları şu şekildedir:

Ö-3: Malzeme yetersizliğinedeniyle çalışmalarımızda da bazı eksiklikler olmaktadır.

0̈-6: Daha önce boya ile karşılaşmadığımdan biraz zorlandım. Atölyede bulunan bazı malzemeleri kullanarak daha eğlenceli ve daha yaratıcı bir resim yapmamı noktasinda yardımci oluyor.

Çeşitlimalzemelerietkilibirşekildekullandırabilmeye ilişkin alınan olumsuz görüşler incelendiğinde ise; öğrencilerin maddî açıdan desteklenmeye ihtiyaç duydukları yönünde görüşler elde edilmiştir. Bu durumun çok önemli olduğu bilinmektedir. Bundan da önemlisi, daha önce boya kullanmadığı yönünde görüş belirten öğrencinin Türkiye'deki bu alanla ilgili eksiklikleri öne çıkarmasıdır. Sanat eğitiminin, yaşam boyu süren, sürmesi gereken bir eğitim modeli olduğu düşünüldüğünde, bir öğrencinin farklı boyama teknikleri ile karşılaşmamasının ötesinde, boya ile karşılaşmaması düşüncesi gerçekten üzerinde ayrıca çalışılması gereken bir durumdur.

0̈-12: Bu derste malzemelerin yetersizliğinin çok da önemli olmadığını ve sadece bir boyayla bile olağanüstü şeyler ortaya koyabileceğimi öğrendim.

Temel tasarım dersinin malzemeyi etkili bir şekilde kullandırabilmesi ile ilgili olarak farklı malzemeleri kullanmanın öz güveni geliştirdiği yönünde görüşler elde edilmiştir.

\section{Ö-2: Farklıboyama teknikleriöğrenirkenaynızamanda} renklerin birbirleri ile olan ilişkisini de öğreniyoruz.

0̈-11: Temel tasarım dersinde kullandığımız malzemeler farklı boya tekniklerini etkin ve özgün bir biçimde kullanmamıza yardımcı oldu.

Boyama tekniklerine ilişkin olumlu kazanımlar olduğu yönünde görüşler dikkat çekmektedir.

0̈-15: Temel tasarım dersinde hiç bilmediğim malzemelerle tanıştım ve bunlarla neler yapabileceğimi öğrendim. Hayal gücümün çok geliştiğini düşünüyorum.

Temel tasarım dersinde farklı malzemelerin kullanımının hayal gücünü geliştirdiği yönünde görüşlere rastlanmıştır.

0̈-11: Temel tasarım dersinde kullandığımız malzemeler farklı boya tekniklerini etkin ve özgün bir biçimde kullanmamıza yardımcı oldu.

Yine farklı malzemelerin kullanımının özgün işler ortaya koymada yardımcı olduğuna ilişkin görüşler alınmıştır.

0̈-5: Malzemelerin doğru biçimde kullanımı 
çalışmalarımızı istediğimiz biçimde gerçekleştirmemizi sağlar. Disiplinli boyama yapmayı öğrenerek bilinçli boyama ve bilinçsiz boyama yapmayı öğretmektedir.

Temel tasarım dersinin çeşitli malzemeleri etkili bir şekilde kullandırabilmesine ilişkin öğrencilerin görüşlerine bakıldığında, öğrencilerden disiplinli çalışma konusunda görüş alınmıştır.

Görüşlere genel olarak bakıldığında; malzeme kullanımına ilişkin alınan görüşlerin yarısı olumlu, diğer yarısı olumsuz görüşlerden oluşmaktadır. Dersin malzemeyi etkin biçimde kullandırdığına ilişkin görüşlerin dersin işleniş biçimine uygun görüşler olduğu düşünülmektedir. Bauhaus'a göre malzeme kullanımı şu şekildedir:

$\mathrm{Bu}$ okulun hocalarından Itten öğrencilerine malzemeye yönelik üç aşamalı çalışma yöntemi uygulamıştır. Birinci aşamada; öğrencilerini gözlem ile elde edilen yapısal özelliklerle düzenlemelere ve geniş malzeme çeşidi ile çalışırken bunların dokusal, yapısal, organik özelliklerini inceleyerek yeni fonksiyonlar, yeni formlararamalarınayönelttiği belirtilmiştir. Íkinciaşamada demir, çöp, kağıt gibi farklı özellikteki malzemeleri ve el aletlerini tanımalarını sağlamaktır. Böylelikle öğrenci hem çeşitli özelliklere sahip malzemeleri tanıyacak hem de bu malzemelerde uygulayabileceği farklı teknikleri ve donanıma hakim olacağı belirtilmiştir. Üçüncü aşamada ise ileriki eğitimleri için gerekli olan tasarım ilkeleri ve elemanlarının öğretilmesi amaçlanmıştır. Bu doğrultuda renk ve form yasaları uygulanmıştır. Bu çalışmalara paralel olarak objektif ve sübjektif formlar renklerle çok yönlü olarak geliştirilip desteklediğinden söz edilmiştir. Sübjektif konu ve formlar ile hayal gücü beslediği vurgulanmıştır (Gökbulut, 1992: 35; Toktaş, 2009: 21'den).

Öte yandan, farklı malzeme ile tanışan öğrencinin farklı teknikleri keşfetme sürecinde öz güveninin geliştiğine ilişkin görüşler elde edilmiştir. Bunun yanı sıra farklı boyama teknikleri ile olumlu kazanımlar elde edildiğine dikkat çekilmiştir. Hayal gücü ve özgünlük bağlamında görüşlerin olduğu da görülmektedir.

Araştırmaya katılan Resim-İ̧ Eğitimi öğrencilerine yöneltilen dördüncü soru 'Temel tasarım dersinin temel sanat eleman ve ilkelerini sanat tarihi ile ilişkilendirebilmenize katkısı hakkındaki düşünceleriniz nelerdir?' şeklinde düzenlenmiştir.

Araştırmada, temel tasarım dersinin temel sanat eleman ve ilkelerini, sanat tarihiyle ilişkilendirebilmeye katkısı ile ilgili olarak bir soru yöneltilmiştir. Araştırmaya katılan öğrenciler olumlu ( $n=17)$ görüşler ortaya koymuşlardır. Öğrencilerin bazılarının görüşleri şu şekildedir:

\begin{tabular}{ll}
\hline Sanat Tarihi Ile flişkisi & f \\
\hline Yol Güsterici & 8 \\
\hline Bakış Açısı & 3 \\
\hline Ozgūnlūk & 2 \\
\hline Gōzlem Gücū & 2 \\
\hline Yaratıcılık & 2
\end{tabular}

Tablo 4: Öğrencilerin “Sanat Tarihi’yle Illişkisi” ile Ilgili Görüşleri

0̈-5: Sanatçıların yapmış oldukları çalışmalar bizlere öncülük ediyor ve daha hızlı ilerlememizi sağlıyor.

0̈-11: Temel tasarımın ayrılmaz bir parçasıdır sanat tarihi, geçmişten alınan örneklerle önümüze geniş bir yelpaze açabiliriz.

Temel sanat eğitimi dersinin temel sanat eleman ve ilkelerini sanat tarihi ile ilişkilendirebilmeye katkısı ile ilgili görüşlere bakıldığında; sanat tarihinin yol gösterici, öncü olduğu konusunda görüşler dikkat çekmektedir.

Ö-2: Bu sayede hiç bilmediğimiz sanatçıların çalışmalarını kendimize örnek aldık. Bu da resme farklı boyutlardan bakmamızı sağladı.

Temel sanat eleman ve ilkelerini sanat tarihi ile ilişkilendirebilmeye katkısı konusunda farklı bakış açıları kazandırdığı yönünde görüşler elde edilmiştir.

0̈-7: Sanat tarihinde incelediğimiz çalışmalar ileriki zamanlarda özgün işler ortaya koymamıza yardımcı olur. 
Sanat tarihinin, üretim aşamasında özgünlük kazandıracağı yönünde görüşler olduğu görülmektedir.

0̈-8: Temel sanat dersinde yaratıcılığımızı ve gözlem gücümüzü geliştirmek için sanat tarihinin bize katkısının büyük olduğunu düşünüyorum.

Temel sanat eleman ve ilkelerinin sanat tarihi ile ilişkisi konusunda katkısının gözlem gücünü artırdığına ilişkin görüşler dikkat çekmektedir.

0̈-8: Temel sanat dersinde yaratıcılığımızı ve gözlem gücümüzü geliştirmek için sanat tarihinin bize katkısının büyük olduğunu düşünüyorum.

Sanat tarihinin bir diğer katkısının da yaratıcılığı geliştirmek yönünde olduğuna ilişkin görüşlerdir.

Temel tasarım dersinin temel sanat eleman ve ilkelerini sanat tarihi ile ilişkilendirebilmeye katkısı ile ilgili görüşlere genel olarak bakıldığında, özellikle bu dersin, yol gösterici olduğuna ilişkin görüşler dikkat çekmektedir. 'Yol gösterici'yi açmak gerekirse, öncülük ettiği ve bunun da gelişimlerindeki hızı artırdığı, sanat tarihinden farklı örnekleri incelemenin kendi üretimlerine farklı açılardan bakabilme konusunda örnek oluşturduğu, geçmişten günümüze sanat tarihinin gelişimine ilişkin birtakım fikirler edindikleri konusunda destek olduğunu belirten görüşler elde edilmiştir. Bunun yanı sıra görüşlerde farklı bakış açıları kazandıkları konusuna da dikkat çekilmiştir. Özgün işler üretmede yardımcı olduğu, gözlem gücünü artırdığı ve yaratıcılığı geliştirdiği gibi görüşlere de rastlanmıştır.

\begin{tabular}{ll}
\hline Yaratıeılık & f \\
\hline Ozgünlük & 5 \\
\hline Bakış Açısı & 5 \\
\hline Hayal Gũcū & 4 \\
\hline Ozgürlūk & 2 \\
\hline Ögüven & 2
\end{tabular}

Tablo 5: Öğrencilerin "Yaratıcılık” ile Ilgili Görüşleri

Araştırmaya katılan Resim-İş Eğitimi öğrencilerine yöneltilen beşinci soru 'Temel tasarım dersinin 'tasarım oluşturmada yaratıcı öneriler geliştirebilmenize’ katkısı hakkındaki düşünceleriniz nelerdir?' şeklinde düzenlenmiştir.

Çalışmada, temel tasarım dersinin tasarım oluşturmada yaratıcı öneriler geliştirebilmeye katkısı ile ilgili olarak bir soru yöneltilmiştir. Araştırmaya katılan öğrenciler olumlu $(n=18)$ görüşler ortaya koymuşlardır. Öğrencilerin bazılarının görüşleri şu şekildedir:

Ö-12: Yaratıcılık kişinin özgün fikirlerini betimlediği için özgürce kendimi yansıtabiliyorum ve sadece kendi istediğim gibi yapıyorum.

Temel tasarım dersinin tasarım oluşturmada yaratıcı öneriler geliştirebilmeye katkısı ile ilgili görüşlere bakıldığında; özgün işler üretmeyi sağladığı ile ilgili görüşler dikkat çekmektedir.

Ö-8: Yaratıcı düşünce sayesinde nesnelere ve olaylara farklı bakmamızı sağlamıştır.

Temel tasarım dersinin farklı bakış açıları geliştirerek yaratıcı öneriler geliştirmeye katkısı olduğuna ilişkin görüşler elde edilmiştir.

0̈-10: Tasarım oluşturmada bu ders bireyin hayal gücünü geliştiriyor.

Yaratıcı öneriler geliştirirken hayal gücünü geliştirdiği yönünde de görüşler alınmıştır.

Ö-12: Yaratıcılık kişinin özgün fikirlerini betimlediği için özgürce kendimi yansıtabiliyorum ve sadece kendi istediğim gibi yapıyorum.

Özgürlük duygusunun, temel tasarım dersinde yaratıcı öneriler geliş̧irmeye katkısına ilişkin görüşler arasında olduğu gözlenmektedir.

0̈-9: Bireyin özgün düşünceleri ortaya çıkar ve bu sayede özgüven gelişir.

Yaratıcı fikirler geliştirirken özgüvenin de geliştiğine dair görüşler elde edilmiştir.

Temel tasarım dersinde yaratıcı düşüncelerin geliştirildiğine ilişkin olumlu görüşler alınmıştır.

Temel Tasarım dersinin en temel amaçlarından biri 
yaratıcı tasarımlar geliştirmektir. Temel Tasarım dersi, tüm duygu ve duyumların farkına varılması, görme ile düşünmenin birleştirilmesi ile görsel algıyı ön plana çıkaran bir etkinliktir. Malzeme ile düşünce arasında çeşitli ve değişik bağlantılar kurulması ve nesne ile çevre arasında estetik bir iletişim sağlanması için yapılan tüm etkinliklerini kapsar (Atar, 2004: 48).

Görüşlere genel olarak bakıldığında; aynı zamanda özgün işler üretimine katkı sağlandığı ve farklı bakış açılarının geliştirildiğine dair görüşler öne çıkmaktadır. Öte yandan hayal gücünün bu durumdan beslendiğine dair görüşler de elde edilmiştir. Aynı zamanda görüşler arasında özgürlük duygusunun da yer alması dikkat çeken önemli bir duygu gelişimi olarak düşünülebilir.

\begin{tabular}{ll}
\hline Sanat Eserleri he hiıski & f \\
\hline Bakış Açısı & 3 \\
\hline Kendini Ifade Etme & 2 \\
\hline Gerçeklik Algısı & 2 \\
\hline Hayal Gücū & 1 \\
\hline Kompozisyon Kurgusu & 1 \\
\hline
\end{tabular}

Tablo 6: Öğrencilerin “Sanat Eserleri’yle Illişki” ile Ilgili Görüşleri

Araştırmaya katılan Resim-İ̧̧ Eğitimi öğrencilerine yöneltilen altıncı soru 'Temel tasarım dersinin 'sanat eserleri ile ilişkili bir şekilde iki ya da üç boyutlu özgün çalışmalar tasarlayabilmenize' katkısı hakkındaki düşünceleriniz nelerdir?' şeklinde düzenlenmiştir.

Araştırmaya katılan öğrenciler olumlu ( $n=9)$ görüşler ortaya koymuşlardır. Öğrencilerin bazılarının görüşleri şu şekildedir:

0̈-8: Gerçeklik boyutuna yaklaşıp daha realist çalışmalar ortaya koymamıza yardımcı olur ve farklı bir bakış açısı kazandııır.

Sanat eserleri ile ilişkili olarak özgün tasarımlar üretme konusunda farklı bakış açıları kazandırdığı yönünde görüşler elde edilmiştir.

0̈-6: Temel tasarım çalışmalarını öğrendikçe 3 boyutlu resimlerle kendimi ifade edebilmem daha rahat oldu.
Kendini ifade edebilme ile ilgili görüşler dikkat çekmektedir.

0̈-17: Boyutlu resimlerde yakaladığımız gerçekçiliği ne yazık ki diğer çizimlerde göremiyoruz, bu da katkısının büyük olduğunu en büyük kanıtı.

Temel tasarım dersinde sanat eserleri ile ilişkiler kurmanın gerçeklik algısını güçlendirdiğine ilişkin görüşler olduğu gözlenmektedir.

0̈-13: Bu boyutlu çalışmalar sayesinde her objeye ayrı bir hacim kazandırmayı öğrendik, bu da bizim hayal gücümüzü geliştirdi.

Sanat eserleriyle ilişkiler kurmanın hayal gücünü geliş̧tirdiğine dair görüş elde edilmiştir.

0̈-5- Farklı tasarımları doğru ve yerinde kompozisyonlarla yapmayı öğrendik.

Uygulamalı çalışmalarda kompozisyon kurgularken, sanat eserleriyle ilişkiler kurmanın katkısının olduğuna dair görüş alınmıştır.

Temel tasarım dersinin sanat eserleri ile ilişkili bir şekilde iki ya da üç boyutlu özgün çalışmalar tasarlayabilmeye katkısı ile ilgili olarak çeşitli görüşler elde edilmiştir. Farklı bakış açısı geliştirdiği yönündeki görüşler dikkat çekmektedir. Sanat eserleriyle ilişkiler kurmanın kendini ifade etmeye katkısına ve gerçeklik algısını geliştirdiğine dair görüşlerin olmasının öğrencinin gelişimi için önemli olduğu düşünülmektedir. Aynı zamanda, hayal gücünün geliştiğine ve kompozisyon kurgularken yardımcı olduğuna dair görüşler alınmıştır. Itten'in öğrencilerine eğitimin bir parçası olarak sanat tarihinin önemli isimlerinden kopya çalışmaları yaptırdığı bilinmektedir.

Araştırmaya katılan Resim-İ̧̧ Eğitimi öğrencilerine yöneltilen yedinci soru 'Temel tasarım dersinin sanat araştırmalarında ve sanat uygulamalarında teknolojiyi kullanabilmenize katkısı hakkındaki düşünceleriniz nelerdir?' şeklinde düzenlenmiştir.. 
Teknoloji Kullanımı

Yol Gösterici

Farkındalık

Uygulamaya Katkısı

Û́slup Oluşturma

Tablo 7: Öğrencilerin“Teknoloji Kullanımı” ile Illgili Görüşleri

Temel Tasarım dersinin etkililiğine ilişkin yapılan araştırmada, temel tasarım dersinin sanat araştırmalarında ve sanat uygulamalarında teknolojiyi kullanabilmeye katkısı ile ilgili olarak bir soru yöneltilmiştir. Araştırmaya katılan öğrenciler olumlu ( $n=13)$ görüşlerin yanı sıra olumsuz $(n=3)$ görüşler de ortaya koymuşlardır. Öğrencilerin bazılarının görüşleri şu şekildedir:

0̈-2: Teknoloji yardımı ile farklı sanatçıların kullandığı farklı teknikleri görüp bunu kendi çalışmalarımızda uygulama firsatı buluyoruz.

0̈-8: Çoğu zaman bazı büyük sanatçıların eserlerini incelemem için tek kaynak teknoloji oluyor. Benim için bu yüzden katkısı büyük.

Teknoloji aracılığıyla birçok bilgiye erişimin sağlandığına ve sanatçı-eser inceleme bağlamında yol gösterici olduğuna ilişkin dikkat çeken görüşler elde edilmiştir.

0̈-12: Teknolojinin son 100 yıl içinde hızla büyümesi sonucunda sanatın kaybettiği bir takım şeylerin farkına varmanın zor olmadığını gördüm.

0̈-16: Geriye dönüp baktığımızda sanat adına şu anki teknolojinin hızına eşit hızda bir gelişmenin söz konusu olduğunu söyleyebiliriz.

Teknolojinin gelişimine paralel sanatın da gelişimi hakkında farkındalık kazanıldığına ilişkin görüşler olduğu gözlenmektedir.

0̈-1: Temel tasarım dersinde uyguladığımız teknikleri teknoloji yardımı ile (çeşitli programlarla) değişiklikler uygulayarak tekrar düzenlememiz konusunda bize katkısı büyük.

Atölye çalışmaları sırasında teknolojinin katkısının önemli olduğu konusunda olumlu görüş alınmıştır.

0̈-6: Bence sanat konusunda teknoloji pek de gerekli değil. Öğrencinin öğretmenine ve kullanılan tekniklere bağlı kalarak çabalaması yeterlidir.

Ö-15: Bazı insanlar teknolojiye bağımlı hale geldiler ve günümüzde göreceli de olsa bazı sanat dallarını icra eden insanlar teknolojiden bağımsız hareket edemez oldu.

Atölye çalışmaları sırasında uygulamaya katkısının olmadığını yönünde olumsuz görüşler de dikkat çekmektedir.

0̈-7: Teknoloji farklı kişilerden ve farklı tarzlardan faydalanabilmemizi ve bu beyin fırtınası içinde kendi tarzımızı oluşturmamıza yardımcı olur.

Teknolojinin üslûp geliştirmeye katkısı olduğu yönünde görüş elde edilmiştir. Görüşler odağında, sanatın gelişiminin teknolojinin hızına paralel geliştiğine dair farkındalık kazanııdığına dair veriler elde edilmiştir. "Sanat bilgiyi, bilgi teknolojiyi üretmekte, teknoloji de üretilen bilginin olgunlaşmasını ve bilginin yaygınlaşmasını sağlamaktadır" (Atan, 2004: 64). Tepecik (2002: 13), Bauhaus'un kurucularından biri olan Walter Gropius'un, sanat ve teknoloji arasındaki ilişkisinden şu şekilde söz eder: "El işçiliğinden endüstriye geçiş, kişisel tecrübeden kolektif deneyime geçiş demektir". Öte yandan, teknolojinin atölyedeki uygulamalı çalışmalara katkısı olduğunu düşünen olumlu görüşlerin yanı sıra olumsuz görüşlerin de yer aldığı görülmektedir. Bunun nedeninin, öğrencilerin teknolojiye yönlendirilme eksikliğinden çok öğrencilerin teknolojiyi nasıl kullanacakları yönünde bir çaba geliştirmedikleriyle ilgili olabileceği düşünülmektedir. Ayrıca, teknolojiyi sanat üretiminde bir bağımlılık olarak görme, sanat üretiminin sadece atölyede öğretim elemanı eşliğinde olabileceği, teknoloji ile sanat eseri üretilemeyeceği gibi eğilimlerin olmasının da biraz gelenekçi bir eğitim modeli ile derslerin işlendiğinin göstergesi olabileceği düşünülmektedir. Oysa çağın teknoloji çağı olduğu düşünüldüğünde öğretim elemanına ve öğrenciye çeşitli 
sorumluluklar düşmektedir. Üretimi teknoloji üzerinden yapma zorunluluğu bulunmamasına rağmen, eser üretiminde teknoloji çoğunlukla araç konumundadır. Bunun göz ardı edilmesi, temel tasarım dersinde eğitim gören öğrencilerin ve eğitimi veren öğretim elemanlarının çağın gerisinden gelmeleri demektir. Günümüzde giderek gelişen iletişim teknolojileri, özellikle sanat gibi alanlar üzerinde önemli bir etkide bulunmaktadır. Bütün bunların yanı sıra teknolojinin sanat üretimi sırasında üslup geliştirmeye katkısı olduğuna dair bir olumlu görüşün de yer alması umut verici olarak düşünülebilir.

Araştırmaya katılan Resim-İ̧̧ Eğitimi öğrencilerine son olarak "Temel tasarım dersi hakkındaki belirtmek istediğiniz başka görüşleriniz varsa lütfen belirtiniz." maddesi yöneltilmiştir. bazılarının görüşleri şu şekildedir:

0̈-11: Bu derste zihnimden şekiller ve kompozisyonlar oluşturuyorum. Bana ait özgün işler ortaya çıkıyor.

Araştırmaya ilişkin elde edilen görüşlere bakıldığında; temel tasarım dersinin özgün işler üretmeye yardımcı olduğu hakkındaki görüşler dikkat çekmektedir.

Ö-3: Bu ders tamamı ile hayal gücü, farklı düşünme ve çok çalışma ile ilerleyebilecek bir ders.

Temel tasarım dersinin çok çalışma gerektirdiği ile ilgili görüşler elde edilmiştir.

0̈-2: Temel tasarım dersi hem eğitici hem öğretici hem de zevkli. Düşündükçe sürekli olarak daha farklı şeyler ortaya koymamıza yardımcı oluyor.

\begin{tabular}{ll} 
Görüş ve Öneriler & f \\
\hline Özgünlük & 3 \\
\hline Aktif Çalışma & 3 \\
\hline Yol Gösterici & 3 \\
\hline Bakış Açısı & 2 \\
\hline Hayal Gücü & 2 \\
\hline Beceriler Toplamı & 2 \\
\hline Görmeyi Öğrenme & 2 \\
\hline Yaratıcılık & 1 \\
\hline Özgüven & 1 \\
\hline Öğretim Elemanlarının Deneyimi & 1 \\
\hline Üslup Oluşturma & 1 \\
\hline Değişimin Somut Algısı & 1 \\
\hline Tasarımın Konusu & 1 \\
\hline
\end{tabular}

Tablo 8: Öğrencilerin “Görüş ve Öneriler” ile Illgili Görüşleri

Temel tasarım dersinin etkililiğine ilişkin yapılan araştırmada, temel tasarım dersi hakkındaki görüşlere ilişkin yöneltilen soruya araştırmaya katılan öğrenciler olumlu $(n=22)$ görüşler ileri sürmüşlerdir. Öğrencilerin
Temel tasarım dersinin, farklı düşünme biçimleri geliştirdiği, aynı zamanda eğitici, öğretici, zevkli olduğuna ve bunlardan hareketle yol gösterici olduğuna dair görüşler alınmıştır. 
0̈-8: Temel tasarımın var olan bakış açımı, hayal gücümü ve yaratıcılığımı geliştirdiğini düşünüyorum. Bakmıyorum görüyorum.

Yine bu dersin, farklı bakış açıları kazandırdığına ilişkin görüşler elde edilmiştir.

0̈-8: Temel tasarımın var olan bakış açımı, hayal gücümü ve yaratıcılığımı geliştirdiğini düşünüyorum. Bakmıyorum görüyorum.

Hayal gücünü geliştirdiği yönünde görüşler olduğu da gözlenmiştir.

0̈-16: Temel tasarım, insan yaşamında ki tüm becerilerin toplamıdır.

Beceriler toplamı ile ilgili görüşlerin olduğu gözlenmiş̧ir.

0̈-8: Temel tasarımın var olan bakış açımı, hayal gücümü ve yaratıcılığımı geliştirdiğini düşünüyorum. Bakmıyorum görüyorum.

Bakmayı değil görmeyi öğrettiğine dair görüşler alınmıştır.

0̈-8: Temel tasarımın var olan bakış açımı, hayal gücümü ve yaratıcılığımı geliştirdiğini düşünüyorum. Bakmıyorum görüyorum.

Yaratıcılığı geliştirdiği yönünde görüş alınmıştır.

0̈-9: Temel tasarım en baştan bilgilenmemizi, kendimize olan özgüvenimizi arttırır. Düşünce açısından geliştirir, çevremizi diğer insanlardan farklı görürüz.

Özgüveni geliştirdiği yönünde görüş alınmıştır.

0̈-6: Hocalarımızın yeteri kadar deneyim ve yeteneğe sahip olduğunu düşünüyorum bu da bizim bu derste ne kadar şanslı olduğumuzu gösteriyor bence.

Deneyimli öğretim elemanlarının öğrencilerin eğitimi açısından önemli bir faktör olduğu konusunda görüş alınmıştır.

0̈-7: Aldığımız bu temel tasarım dersi tarzımızı geliştirmemize veya kendimize yeni tarz bulmamıza yardımcı olur böylece özgünlük de ortaya çıkar.

Üslup oluşturma aşamasında bu dersin katkısının önemli olduğuna ilişkin görüş olduğu gözlenmektedir.

Araştırmada, öğrencilerden temel tasarım dersi hakkında çeşitli görüşler alınmıştır. Görüşlere genel olarak bakıldığında; özellikle temel tasarım dersinin özgün işler üretmede, aktif çalışmada etkisi olduğu konusundaki ve bu dersin yol gösterici bir ders olduğuna ilişkin görüşlerin öne çıktığı görülmektedir. Ayrıca farklı bakış açısını, hayal gücünü geliştirdiği, bakmayı değil görmeyi öğrettiği yönündeki görüşlerin yanı sıra dersin beceriler toplamı olduğuna dair görüşlerin olması da dikkat çekmektedir. Aynı zamanda yaratıcılığı ve özgüveni geliştirdiği, üslup oluşturmada etkili olduğu ve öğretim elemanlarının deneyimlerinin de önemli olduğuna ilişkin görüşler de görülmektedir. Öte yandan değişimlerin yansıtıldığı bir ders olduğu konusuna da vurgu yapılmıştır.

Araştırmada öğrencilerin temel tasarım dersi ile ilgili görüşleri şu şekilde boyutlandırılmıştır:(Şekil1)

\section{Sonuç ve Tartışma}

Temel tasarım eğitiminde ana hedeflerden biri öğrencilere kuramsal ve uygulamalı olarak temel eleman ve ilkeleri kavratmaktır. Bu bağlamda dersin içeriği de buna göre yönlendirilmelidir. Dersin diğer hedeflerinden biri ise, disipline olmayı öğrenmedir. Öğrenciler öğrendiklerini uygularken temiz ve titiz çalışmaya, zamanı iyi kullanmaya, sabırlı bir şekilde ürün üzerinde odaklanmaya vb. sevk edilirler. Bu türden bir eğitim ise onları sonra yapacakları çalışmalarda yönlendirici etkiye sahiptir. Ayrıca temel tasarım dersi ve genel olarak sanat eğitimi sürecinin diğer hedeflerinden biri de bakma ve görme arasındaki farkın algılanmasıdır. Bu algıyı geliştirme çabaları içerisinde temel tasarım dersi uzun soluklu bir eğitim sürecinin en önemli parçasını oluşturmaktadır. Öğrenciler bu derste gerekli donanımları kazanırlarsa, sanat eğitimi sürecinin devamında daha öz güvenli, özgür, yaratıcı, özgün vb. olabilirler.

Temel tasarım dersi, eleman ve ilkeleri özgün 
tasarımlar şeklinde uygulamayı sağlarken, özellikle de yaratıcı düşünmeyi ön plana çıkarmaktadır. Bu durum öğrencilerin kazanımları açısından önemli görülmektedir. Itten'in Bauhaus'dan ayrıldıktan sonra yazdığı 'Design and Form' (Tasarım ve Biçim) kitabında temel tasarım dersinin öğrencinin yaratıcı güçlerini serbest bırakan, geleneksel sanat tavrından yavaş yavaş uzaklaşılarak, özgürleştirerek yaptıkları çalışmalarda onları cesaretlendirerek algı ve deneyimlerini tamamen kendi işlerine yansıttıklarından söz eder. Ayrıca öğrencinin kariyer seçimini kolaylaştırarak malzeme ve doku çalışmalarıyla kendine uygun malzemeyi elde etmesi sağlanmıştır. Renk ve form konularında da aynı titizlikle hareket edilerek öğrencilerin dünyaya objektif bakmaları sağlanmıştır (Itten, 1967: 9). Temel tasarım eğitiminin yaratıcı düşünmenin yanı sıra genel olarak öğrenciye kazandırdıkları; yol gösteren olması, sınırları ortadan kaldıran bir özgürlük sunması, soyut ve somut düşünme biçimlerini geliştirmesi, bireysel farklılıkları ortaya çıkarması, kişide öz güveni ve hayal gücünü geliştirmesi, diğer alanlarla ilişkiler kurmayı sağlaması olarak sayılabilir. Türk Resim Sanatının önemli isimlerinden Halil Akdeniz ve Erdal Aksel'in temel tasarım dersinde öğrencilerin öznel düşünmeye, risklere girebilmeye, düşünmede bağlantısız sıçramalar yapabilmeye, fikirleri eş zamanlı geliştirerek yeni yorumlara ulaşabilme ve problem çözme yollarını özgürce denemeye teşvik edilmelerinden söz ederler (Akdeniz ve Aksel, 1989: 15). Bütün bunlar öğrencilerin temel tasarım dersinde eleman ve ilkelerle özgün tasarımlar üretme sırasında ne denli donanımlı yetiştiklerine dair gösterge olarak sunulabilir.

Temel tasarım dersinde çeşitli malzemelerin etkin kullanıldığına ilişkin tespitler, öğrencilerin bu anlamda donanımlı hale getirildiklerine dair somut göstergelerdir. Öğrenciler farklı malzemelerle farklı teknikleri uygulayabilecekleri seviyeye gelerek malzeme kullanımına ilişkin özgüven geliştirdiklerini belirtmişlerdir. Bu bulgu sanat eğitimi alan bireyler için önemli bir bulgudur; çünkü kendine güvenmeyen birey yaratıcı, özgün işler üretmede, kendini ifade etmede

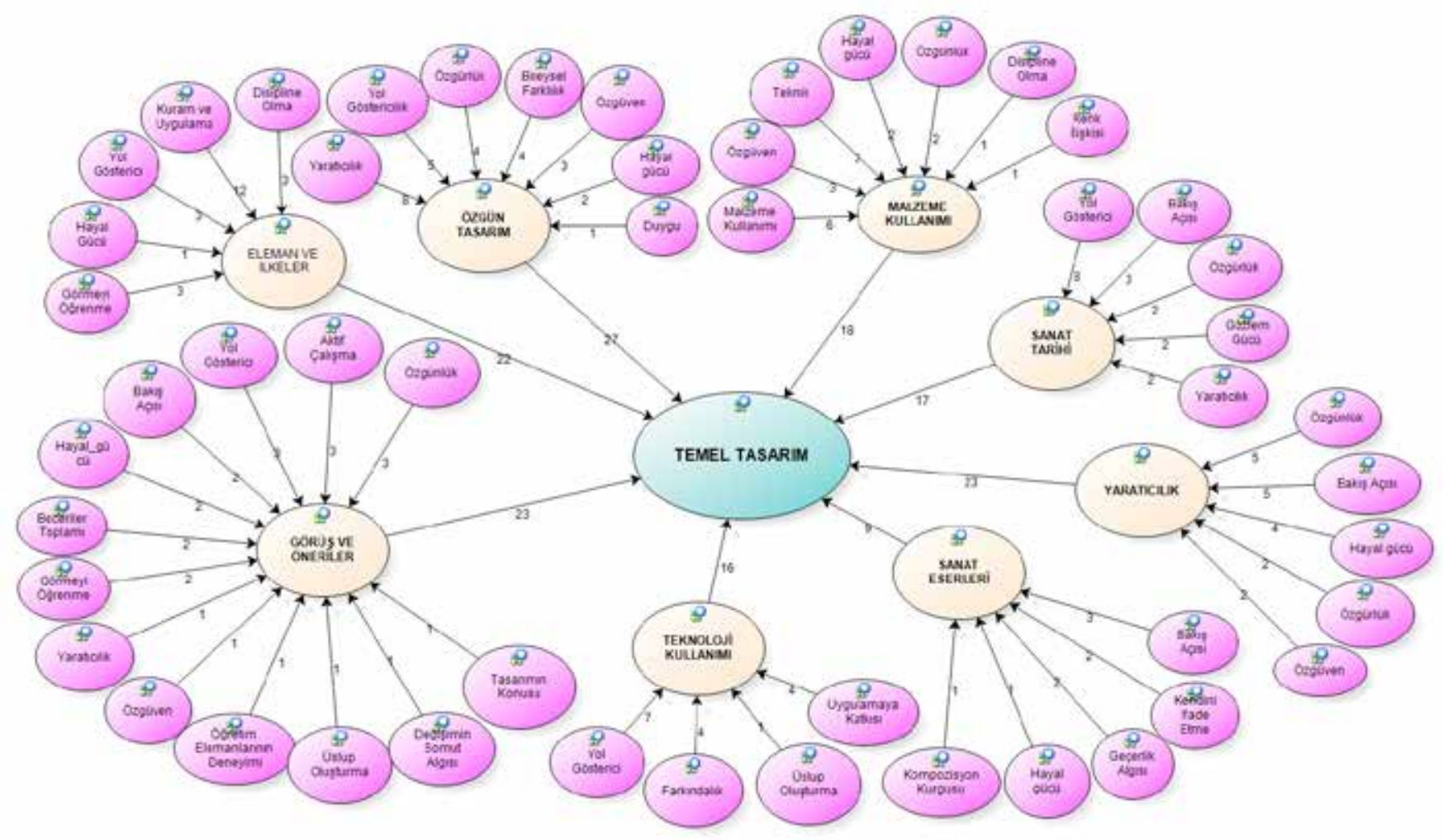

Şekil 1: Temel tasarım dersine ilişkin öğrencilerin boyutlandırılmış görüşleri. 
sorunlar yaşar ve bireysel olarak farklılığı olduğunun bilincine varamaz. Çeşitli malzeme kullanımının hayal gücünü beslediği ve özgün işler üretmede yardımcı olduğu konusundaki düşünceler de dersin katkısına ilişkin olumlu gelişmeler olarak sunulabilir. Ancak temel tasarım dersinin maddi imkânsızlıklar nedeniyle öğrencileri olumsuz etkilediği de bilinmektedir. Bulgular arasında boya ile hiç karşılaşmayan, malzeme yetersizliğinden yakınan öğrencilerin olması Türkiye'de bu bölümü okumanın zorluğuna işaret etmektedir. Öte yandan boya ile hiç karşılaşılmaması Türkiye'de sanat eğitiminin her seviyede verilemediği ve verildiği düzeylerde de yetersiz kaldığı gerçeğini ortaya koymaktadır.

Temel tasarım dersi sanat tarihi süreci ile harmanlanarak anlatılması gereken bir ders olarak yol göstericidir. Öğrencilerin gelişirken daha da hızlı kavramalarında, farklı üretimleri görerek farklı bakış açıları geliştirmelerinde sanat tarihi sürecini geçmişten bugüne takip etmeleri önemlidir. Gözlem gücünün artırılması yaratıcı ve özgün işler üretiminde deneyimlerini çoğaltacaktır.

Yaratıcı bireyler yetiştirmede temel eğitim dersi olan bu ders, doğal olarak bu durumu yani yaratıcılık yönünü besleyen uygulamalı çalışmalar üretmeye ve kuramsal desteklere intiyaç duyacaktır. Yaratıcı yönü geliştirilen öğrencinin özgün işler üretmesi, farklı bakış açıları geliştirmesi, hayal gücünün gelişmiş olması, özgür bir ruha sahip olması ve kendine güven duygusunun gelişmiş olması doğal bir sonuç olarak görülmektedir. Olumlu görüşlerin bu başlıklar altında toplanıyor olması da dersin yaratıcı birey yetiştirme anlamında hedefine ulaştığı anlamına gelmektedir. Özellikle de bu eğitim sırasında özgürlük duygusunun varlığı disiplinli bir ders olan bu derste ulaşılan güzel bir sonuç olarak düşünülebilir.

Sanat eserleriyle ilişkili bir şekilde özgün çalışmalar tasarlayabilme anlamında öğrencilere bol bol örnek çalışmalar gösterilmeli ve kimi zaman bir sanat eserinden hareketle yeniden üretmeleri sağlanmalıdır. Bu türden bir eğitim modeli öğrencilerin farklı bakış açıları kazanmaları, hayal güçlerini geliştirmeleri ve kendilerini ifade etmelerinde çok önemli görülmektedir. Eleman ve ilkelerle ilgili kuramsal ve uygulamalı eğitimlerini destekleyecek türden sanat eseri örnekleri incelemek öğrencilerin verilen bilgileri daha hızı kavramalarında ve uygulamalarında yardımcı olacaktır.

Temel tasarım dersinin, çağımız ortamı düşünüldüğünde teknolojiden bağımsız bir ders olarak işlenmesi düşünülemez. Sanat araştırmaları ve uygulamaları sırasında teknoloji çok önemli bir araç rolündedir. Teknoloji birinci sınıfta bu türden bir araç konumunda iken, ilerleyen sınıflarda sanat üretiminin sadece teknoloji üzerinden yapıldığı bir teknik olarak görülebilir. Ancak teknolojinin gerekli olmadığı, bağımlıık yarattığı vb. görüşlerin olması bir yandan öğrencilerin teknolojiyi nasıl kullanacaklarıyla ilgili olumlu bir çaba geliştirmedikleri sonuca götürürken, bir yandan da gelenekçi bir eğitim modelini çağrıştırmaktadır. Bu noktada Ahmet Şinasi Işler'in 2001 yılında yazdığı 'Temel Sanat Eğitiminde Bilgisayarın Yeri ve iş̧levi’ başlıklı doktora düzeyindeki tez çalışmasında, bilgisayarın getirilerinden ve bilgisayarla mümkün olmayan katkılardan söz eder. İşler'e göre (2001: 79), bilgisayar kullanan öğrencilerin temel sanat eğitimi için önemli olan problem çözme becerilerinin geliştirilmesinde çok alıştırma yapma imkanı bularak, yaratıcı süreçte ilişkiler ve benzerlikler bulmayı, mantıklı ve sıralı düşünerek deneyim elde edilebileceklerinden söz eder. Öğrenciler internet üzerinden kaynaklara ulaşabilir ve açık uçlu programlar sayesinde keşfederek öğrenme imkanı bulurlar. Öte yandan risk alma korkusunu azaltarak özerklik sağlayabilirler. Bilgisayarın kazandıramayacağı nitelikleri ise şöyle belirtir; öğretmenin etkileşimi, yeterli duyusal yaşantı sağlanması ve her öğrenci ile birebir iletişim noktasında yaşanılacak olumsuzluklar. Teknolojinin olumsuz bir şey olarak algılanması öğrencinin gelişimi açısından olumsuz bir sonuç doğurabilirken, diğer yandan da çağın gerisinden takibe neden olabilir. Bu bağlamda öğrenciye ve öğretim elemanına birtakım sorumluluklar düşmektedir. Yaşanan çağda teknolojinin göz ardı edilmesi 
sanat eğitimi ve üretimleri açısından olumsuz bir durum olarak düşünülmektedir.

Genel olarak bakıldığında, lisans düzeyinde okutulan temel tasarım dersine yönelik her bir soru için verilen cevapların etkililiğine ilişkin olumlu sonuçlar elde edilmiştir.

\section{Kaynakça}

Akdeniz, Halil ve Erdağ., Aksel (1989). “Güzel Sanatlar Fakültelerinde Temel Sanat Eğitimi Üzerine Düşünceler ve Bir Bakış Açısı" Güzel Sanatlar Fakültelerinde Temel Sanat Eğitimi, Hacettepe Ünv. G.S.F. Seminer Eğitimi, HÜ. G.S.F. Yay. Ankara.

Atan, Ahmet (2004). Verimli Bir Sanat Eğitimi Için Plastik Sanat Eğitimi Bölümü, II. Sanat Eğitimi Sempozyumu (Bildiriler Kitabı), Ankara: Gündüz Eğitim ve Yayıncılık.

Atar, Nükhet (2004). "Anadolu Güzel Sanatlar Liselerinde Temel Sanat Eğitimi Uygulamalarının Sorgulanması ve Öneriler", Anadolu Üniversitesi Güzel Sanatlar Fakültesi Anadolu Sanat Dergisi (15): 47-54.

Buyurgan, Serap ve Buyurgan, Ufuk (2001). Sanat Eğitimi ve Öğretimi, Ankara: Dersal Yayıncılık.

Bingöl, Yüksel (1993). “Bauhaus ve Endüstriyel Gelişmenin Sanat Eğitimine Etkileri”. Hacettepe Üniversitesi Güzel Sanatlar Fakültesi Sempozyumu, 20-23 Mayıs, Ankara: Hacettepe Üniversitesi Yayınları.

Deliduman, Gence, Canan (2007). “Temel Sanat Eğitiminde Yöntemlere İlişkin Görüş ve Öneriler”, Meslek Eğitim Fakültesi Dergisi 2 (3): 296-313.

Fiedler, Jeannine ve Feierabend, Peter (2000). Bauhaus, Berlin: Published by Konemann.

Gümrah, Himmet (2002). "Sanat Eğitimcisi Yetiştirmede Temel Sanat Eğitimi Dersinin Yeri ve Önemi”, Sanat Eğitimi Sempozyumu, Gazi Üniversitesi Gazi Eğitim Fakültesi 08-09-10 Mayıs.

Gökbulut, Nur. (1992). Temel Sanat Eğitiminde Görsel Alanın Arındırılmasına İlişkin Bir Uygulama Örneği. Yayınlanmamış Yüksek Lisans Tezi, Ankara: Gazi Üniversitesi Sosyal Bilimler Enstitüsü.

Itten, Johannes (1967). Design and Form: The Basic Course at the Bauhaus. London: Thames and Hudson.
İşler, Ahmet Şinasi (2001). Temel Sanat Eğitiminde Bilgisayarın Yeri ve Işslevi, Yayımlanmamış Sanatta Yeterlilik Tezi, İstanbul: Marmara Üniversitesi Sosyal Bilimler Enstitüsü.

Lynton, Norbert (1982). Modern Sanatın Öyküsü, İstanbul: Remzi Kitapevi Yayınları.

Seylan, Ali (2005). Temel Tasarım, Samsun: Dağdelen Basın Yayın Ltd. Şti.

Tepecik, Adnan (2002). Grafik Sanatlar. Ankara: Detay Yayıncılık.

Toktaş, Pınar (2009). Güzel Sanatlar Eğitimi Veren Yüksek Öğretim Kurumlarında Temel Sanat Eğitimi/Temel Tasarım Dersine İlişkin Öğretim Elemanı ve Öğrenci Görüşlerinin Değerlendirilmesi. Yayınlanmış Doktora Tezi, Ankara: Gazi Üniversitesi Eğitim Bilimleri Enstitüsü.

Turani, Adnan (1998). Sanat Terimleri Sözlüğü, İstanbul: Remzi Kitabevi Yayınları.

Yıldırım, Ali ve Şimşek, Hasan (2005). Yıldırım, Nitel Araştırma Yöntemleri (5. Baskı). Ankara: Seçkin Yayıncılık.

\section{Internet Kaynakları}

YÖK (2010).

Resim-İş Öğretmenliği Lisans Programı-Temel Tasarım I-Temel Tasarım II Dersi Ders içerikleri, http://www.yok.gov. tr/documents/10279/49665/resim_is.pdf/ (10 Nisan 2015) 